\title{
空調システムの循環動力の省エネルギ一実証実験 \\ Proof experiment of energy saving for air-conditioning system with drag-reducing additive (LSP-01)
}

\author{
○德原 慶二（(財) 周南地場産センター) \\ Keiji Tokuhara \\ Shunan Regional Industries Promotion Center, 2-118-24 Kokai, Shunan, Yamaguchi,745-0814 Japan
}

\begin{abstract}
We have developed a suitable drag reduction additive(LSP-01) and applied the additive for more than 120 practical distinct heating and cooling systems. As an example, the proof verification of the Sapporo city office is reported in this paper and the approach for the energy saving technology with LSP-01 is presented.
\end{abstract}

\section{Drag Reduction, Surfactant, Energy Saving, Air Conditioning System, Pipe Flow}

\section{1.はじめに}

(財) 周南地域地場産業振興センターは、産業振興の立場か ら 1991 年に産学公から構成する研究会グルーブ (LSP 研究会 山口目内の企業と山口大学) を発足させた。本グルーブは抵 抗低減効果の実用化技術の開発を目的とし、界面活性剂を用 いた抵抗低減剤（LSP-01）を全国に先駆けて製品化した。ま た、冷温水空調等の泠温水ポンブの循環動力の省エネルギー 技術としての導入を行ってきた。開発当初は、山口目内の公 共施設での適用試験 1"を行い、その知見をもとに全国展開を 進めてきたが、近年では（独）産業技術総合研究所の共同研 究事業 (於札幌市役所本打舎) に执いて実証実験 ${ }^{2)}$ を行って いる。本稿ではこれら抵抗低減技術を用いた省エネルギーの 取り組みについて報告する。

\section{2. 界面活性剂について}

抵抗低減（DR；Drag Reduction）効果が起きる界自活性剤 としては複数のものが研究されている。いずれも図 1 に示す ような棒状ミセルの形成が DR 効果の発現に起因するといわ れている。このうち、カチオン采 (四級アンモニウム塩) で 炭素数が 16 のCTAC（塩化セチルトリメチルアンモニウム） や炭素数が 18 のSTAC(塩化セチルトリメチルアンモニウム) については、1990 年代から㕕く研究に使用されてきているが、 我々の結果では泠暖房設備に適用するには温度条件に問題 があることが指摘された。すなわち、CTAC は常温範囲では DR 効果を示すものの、低温域で効果が失われる。一方、STAC はより高温域 $\left(70^{\circ} \mathrm{C}\right.$ 近辺) まで DR 効果を示寸利点があるが、 低温域では CTAC 同様、析出が起こる。これに対し、STAC と 親水基の構造が異なるオレイルビスヒドロキシエチルメチ ルクロライド $\left(\mathrm{C}_{18} \mathrm{H}_{33} \mathrm{~N}^{+}\left(\mathrm{C}_{2} \mathrm{H}_{1} \mathrm{OH}\right){ }_{2} \mathrm{CH}_{3} \mathrm{Cl}^{-}\right)$は、一般的な空 調用冷暖房設備に利用できる温度特性を示すことが判った。 そこで、これを主成とし、対イオンとしてサリチル酸ナトリ ウム $\left(\mathrm{C}_{6} \mathrm{H}_{4}(\mathrm{OH}) \mathrm{COONa}\right)$ を配合した添加剤を開発した。これは 琴在、空調設備等の循環系で一番多く使用されているものて ある。一方、実設備に導入する場合は、配管の防食も重要で ある。そこで、LSP-01 には DR 効果を阻害しない防食剤を含 有させている。

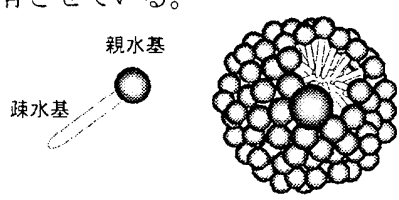

界面活性剂単分子
球状ミセル

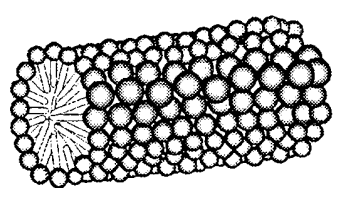

捧狱ミセル

\section{3. 適用条件}

空調システムは熱源、循環ボンプ、空調機（AHU：エアー ハンドリングュニット、FCU：ファンコイルユニット)、抽 びこれらをつなぐ配管采で構成されている。しかし、その詳 細は設備によって様々である。たとえば、熱源としては、吸 収式冷温水発生機、ヒートボンブ、熱交換式（高温蒸気）、 ボイラー\&チラーが挙げられ、設備の運転、制御についても、 負荷の状況により温度を関知して風量を制御するものや、熱 源を制御するもの、弁の開閉により循環水を熱源に戻すもの、 また循環水流量を変化させるものなどある。このように、配 管抵抗低減剤を導入する場合、事前に調査すべき項目は少な くなく、一般的には下記のようなものが挙げられる。

(1) 密閉系の泠温水系であること。(クーリングタワー、冷 却水等では使用できない。)

(2) 配管系統、管径や管付属物を図面や現場で確認する。

(3) 配管長が極端に短くないことを確認する。（一般空調設 備ではまず問題になることはないが、例えば、熱源のそ ばに空調機設置してある場合などは大きな効果は期待 できない。)

(4) 運転方法や管内流速、泠温水温度を調查・計測する。 （ISP-01 の場合、泠温水温度が $5^{\circ} \mathrm{C} \sim 65^{\circ} \mathrm{C}$ で有効である。 一般冷水は $10^{\circ} \mathrm{C}$ 前後、高温は $50 \sim 60^{\circ} \mathrm{C}$ が多い。)

(5) 水質分析を行う。抵抗低減効果は油分があると効果が減 少また消滅することもある。また、防食剤を使用してい る設備は、保有水の希釈、排出が必要な場合もある。

(6) 抵抗低減剤の濃度管理は重要である。定期的にサンブリ ングして濃度分析を行う体制を検討しておく。

\section{4. 札幌本庁舎での実証実験}

\section{4-1 経緯}

周南地場産センターは、(独) 產業技術総合研究所エネ ルギー技術研究部門、札幌市、東京理科大学理工学部、(株) 藤原環境科学研究所と共同で、札幌本庁舎の空調設備にお いて、抵抗低減剤の実証実験を行った ${ }^{2)}$ 。寒冷地での本格 的な実証はこの取り組みが初めてであり、寒冷地で暖房運 転を長期行った場合の影響や冬期の早朝に設備を起動す る際の影響など、有用な知見が多く得られた。民間施設で の試験の場合、データ公開に限度があるが、本試験は公的 機関による実証政究を介して、データ蓄積と公表を行い、 抵抗低減技術の一般化、普及を行うことが目的とされた。 このため、札幌市及び管理会社の協力のもと、実験を行う ことができた。

\section{$4-2$ 導入設備概要}

対象設備は冷温水空調システムであり、その概要を図 2 に示す。暖房は外部より熱源水汃供給され、熱交換器に 


\section{札幌市役所冷暖房システム循環水系統図}

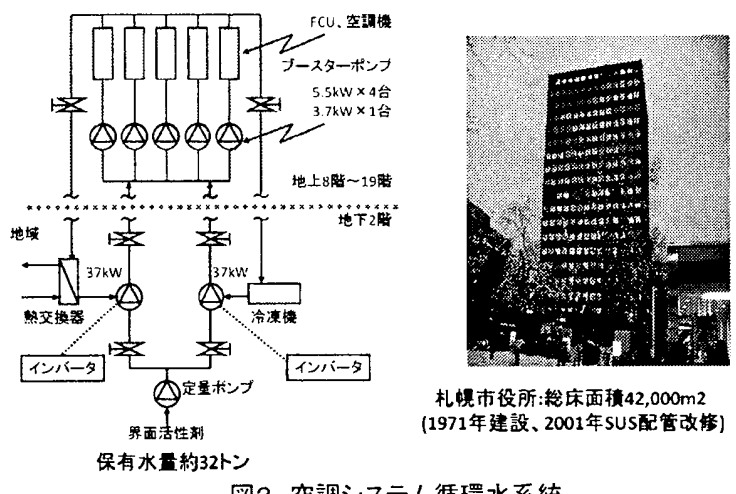

図2 空調システム循環水系統

よって熱交換する。冷房は単効用吸収式冷凍機(熱交換機 チューブ長さ約 $6 \mathrm{~m}$ 、外形 $19 \mathrm{~mm}$ ）が使用されている。設備の 稼働時間は 1 日約 10 時間であり、ボンブは地階の主要循環 ボンブが $37 \mathrm{kw} \times 2$ 台、 $8 \mathrm{~F}$ 機械室にはブースターボンブ $5.5 \mathrm{kw}$ $\times 4$ 台、3. $7 \mathrm{kw} \times 1$ 台がある。ボンプの仕椂は以下の通りで ある。

○高層部用ボンブ 定格 $6,610(1 / \mathrm{m} \mathrm{i} \mathrm{n})$

OAHU 系ボンブ

・基淮階事務空東系統空調機用冷温水ボンブ 定格 $1,600(1 / \mathrm{min})$

- $19 \mathrm{~F}$ 空調機泠温水ポンブ 定格 $1,300(1 / \mathrm{m} \mathrm{i} \mathrm{n})$

・基準階事務室西系統空調機用冷温水ボンブ 定格 $1,420(1 / \mathrm{min})$ 合計 $4,320(1 / \mathrm{m} \mathrm{in})$

OFCU 采ボンフ

・高層部 FCU NE 系統冷温水ポンプ 定格 $713(1 / \mathrm{min})$

・高層部 FCU SW 系統冷温水ポンブ 定格 $1,037(1 / \mathrm{m} \mathrm{i} \mathrm{n})$ 合計 $1,750(1 / \mathrm{min})$

\section{4-3 配管抵抗低隇剤とその投入}

配管抵抗低減剂は LSP-011（エルエスビ一協同組合）を 使用した。図 3 は内径 $10.7 \mathrm{~mm}$ の直管を使用し、6.2 70 ${ }^{\circ} \mathrm{C}$ の温度範囲で LSP-01A $5000 \mathrm{ppm}$ 添加した水道水について 抵抗低減唁を測定した結果である(東京理科大川口研究室 で実施)。

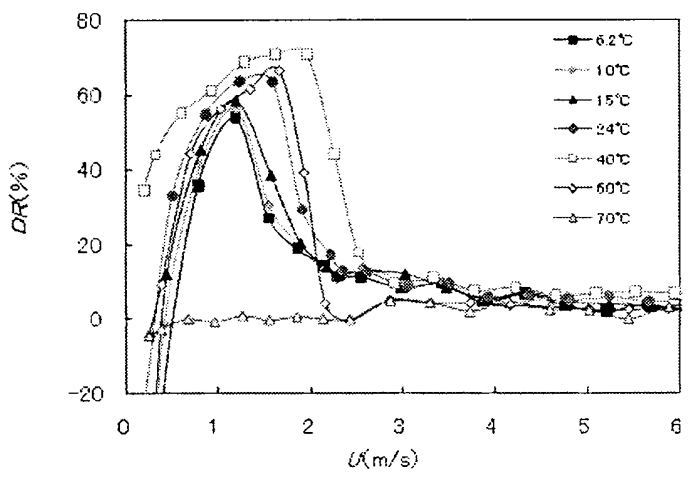

図3 LSP-01A $(5000 \mathrm{ppm})$ 添加水の流速とDRの関係の 温度依存性 (管内径 $=10.7 \mathrm{~mm}$ )
これより $40^{\circ} \mathrm{C}$ 近辺で抵抗低減率が最大值を示しており、さ らに広籁囲の流速域でも効果があることが確認できる。本宁 舎の循環水の温度も $40^{\circ} \mathrm{C}$ 付近で運転されており、DR 効果を 示す最適な条件であったことが指摘された。

本実証試験はまず、暖房時から実施した。LSP-01 の添加は 全量を・日で入れるのではなく、少量ずつ添加をしていき、 途中、サンブリングや濃度チェックをしながら作業や測定を 行った。図 4 は注入ボンブを使用した LSP-01 の添加を示し た写真である。まず LSP-01 を $40 \mathrm{~kg}$ 投入し、翌日に $60 \mathrm{~kg}$ を 追加投入した。この時、LSP-01 の濃度は 3000ppm となる。約 1 週間をかけて $80 \mathrm{~kg}$ を恖加投入し、合計 $180 \mathrm{~kg}$ を投入した。 これにより、最終的な濃度は5900ppm となった。この濃度は、 規定量 $(5000 \mathrm{ppm})$ よりやや多めとなったが、これは市販の 防食剂と併用したことに対する配慮と、配管内壁への剤の吸 着などを考慮した結果である。冷房試験では、暖房から冷房 小ら切り替える際に系内の水が排水されるため、60kg の LSP-01 を追加投入した。投入直後は、5900ppmであり、この 条件で試験を行った。
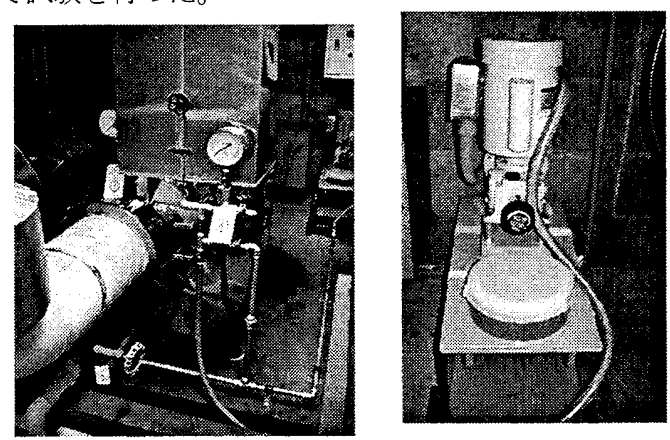

図4 注入ポンプの外観(圧力計部より注入)

循環水量の測定のため、AHU 系、およびFCU 系にそれぞれ に超音波流量計を設置した。测定值はデータロガーに蓄積し、 解析した。LSP-01 を添加していき、循環水量の増加が確認さ れると、循環ボンブのインバーターで皦波数を落としながら 流量を測定し、最終的な省工ネ運転周波数を決定した。

\section{4-4 測定結果とその分析}

LSP-01 の添加途中で循環ボンブの周波数を変化させ、流量 を测定した（表 1、図 5〜8）。最終的には予定した添加量を 全量入れた場合に最高の流量増加が得られ、その結果を元に インバーターの設定周波数を決定した。これより、暖房は $35 \mathrm{~Hz}$ の運転で各系統において定格流量が得られた。このとき 電力量は $65 \%$ の削減となり、同様に泠房時は $40 \mathrm{~Hz}$ で $50 \%$ の 省エネルギーを達成することができた。現在もこの運転条件 が維持されているが、各システムの不具合は全く確認されず、 省エネ効果も持続している。

札幌本序舎での結果はこれまでの実績例 (3), 4) と比較すると かなり省工ネ效果が大きいといえる。その理由注々考えら れる。配管系の総延長が比較的長く、流速条件や暖裳時の循 環水洫度も LSP-01 にとって最適条件であった。また、注目 すべき項目として配管の材質も安定的な運転に大きく奇与 していると考えている。この設備ではステンレス(SUS)管が 施されて㧍り、かつ、防食剂が使用されていることから、管 内抵抗が腐食により增加することも少ない上、I.SP-01 の吸着 も少ないことが予想される。

今回の実証実験では、主要ボンブの高層部用ボンブ $37 \mathrm{kw}$ にインバーターを設置して周波数を変化させる実験を行っ たが、ブースターホンブのAHU 采䇽よびFCU 系ポンブには設 置しておらず定格での運転を行っている。今後、この系列の ボンブもインバーター制御すれば、さらに省エネ化が図れる 可能性を持っているといえる。 
表1 各周波数の流量結果 (暖房)

\begin{tabular}{|c|c|c|c|c|c|c|}
\hline 周浪数 & \multicolumn{3}{|c|}{$3700 \mathrm{ppm}$ 量 $(1 / \mathrm{min})$} & \multicolumn{3}{|c|}{5500 ppm 徒金 $(1 / \mathrm{min})$} \\
\hline $\mathrm{Hz}$ & 全系珫遗以 & AHU往き & 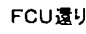 & 全系㧤逗り & AHU往を & FCU缱り \\
\hline 30 & 5830 & 3950 & 1870 & 6144 & 3941 & 1840 \\
\hline 35 & 6450 & 4360 & 1930 & 6610 & 4342 & 1902 \\
\hline 40 & 6960 & 4790 & 2000 & 6820 & 4760 & 1963 \\
\hline 45 & 7470 & 5170 & 2080 & 7290 & 5143 & 2048 \\
\hline 50 & 7960 & 5630 & 2160 & 7800 & 5560 & 2130 \\
\hline 定挌 & & & & 6,610 & 4,320 & 1,750 \\
\hline
\end{tabular}

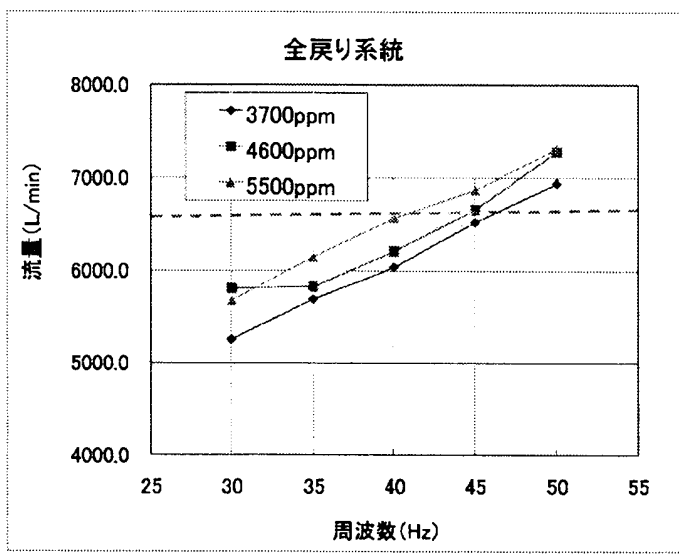

図5 各湍度の周波数と流量の関係(全戻り冷房)

表 1 に暖房時の各周波数の流量結果を示し、図 $5 \sim 7$ には 冷房時の結果を示す。冷房の場合、高層部用ボンプは定格 $6,610 \mathrm{l} / \mathrm{min}$ なので、周波数 $40 \mathrm{~Hz}$ 連転でほぼ一致する。トー タルAHU系ボンブは、4, 320/min であり、F C U系は、 1,750/min であり、LSP5500ppm を添加した場合、いずれも 流量に余裕があるのも確認された。これらのデータにより、 暖房運転は、 $35 \mathrm{~Hz}$ 運転で冷房運転は $40 \mathrm{~Hz}$ 運転に決定した。 高層部用ボンブの循環動力は暖房 $65 \%$ 削減、冷芳 $50 \%$ 削減効果が得られた。

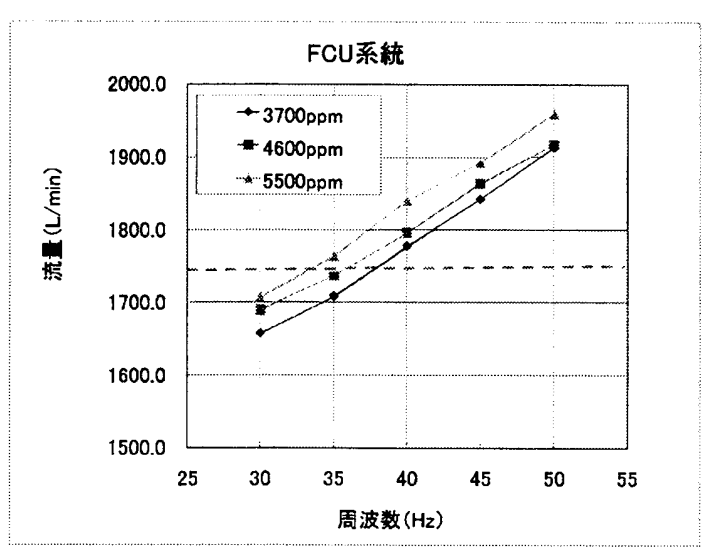

図6 各濃度の周波数と流量の関係(FCU冷房)

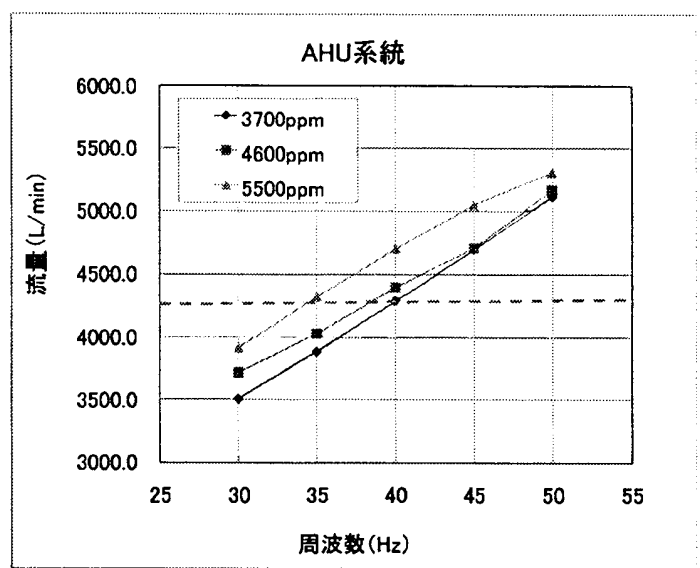

図7 各濃度の周波数之流量の関係(AHU冷房)

\section{4-5 運転の管理について}

札幌市役所本庁舎での実証実験後も(独) 産総研、札幌市、 本庁管理会社と連携して循環水のサンブリングを行い、水質 の分析を定期的に行っている。冷房・暖房時の切り替え時に は系内の水が排水されるため、分析結果を見て追加投入を 行っているが、これまでの結果から、年に 2 回の冷暖房の切 り替え時には最低行うことが良いと考えている。ただし、こ の設備はボンブ周りからの漏れがほとんどなく、漏水とブ ローによる LSP-01 の濃度低下は少ない。しかし、一般的に は漏れが多い設備は多々見受けられ、このような場合は、サ ンプリング回数を增やすなどして、管理する必要があるとい える。

本竹舎導入後、 2009 年 8 月時点で 1000 日目が経過してい るが、現在も流量も維持、濃度も安定していることが確認で きている。現場での簡易的な管理方法としては、導電率によ る急激な濃度低下のチェック（図 8) 及びマグネットスター ラーによる渦試験がある。後者はワイゼンベルク効果を利用 して、スターラーの攪找で発牛する渦の大きさから粘弾性を 簡易的に確認するものである。また、比色法による防食郕主 成分の重硝酸イオン濃度での確認も行っている。

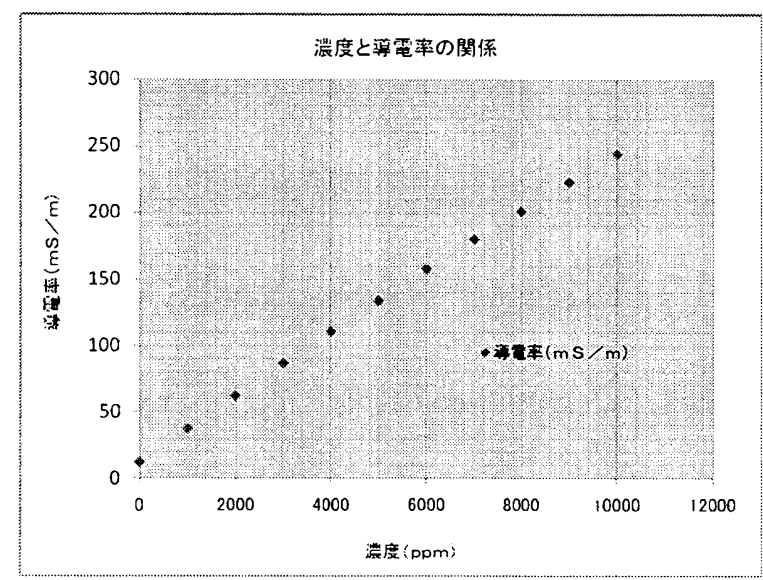

図8 LSP-01A の各㴽度の導電率 
表2 LSP投入後の濃度分析とその経過

\begin{tabular}{|c|c|c|c|c|c|c|}
\hline \multirow{2}{*}{\multicolumn{2}{|c|}{ B付 }} & 日数 & 添加量 & 界面活性 & 対イオン剌 & 雪顶伝腜度 \\
\hline & & (日) & (kg) & $(\mathrm{mg} / \mathrm{l})$ & $(\mathrm{mg} / \mathrm{l})$ & $(\mathrm{ms} / \mathrm{m})$ \\
\hline 2006 & & 0 & 0 & 0 & 0 & 134 \\
\hline 2006 & 11月28日 & 1 & 40 & & & \\
\hline 2006 & 11月29日 & 2 & 60 & 300 & 160 & 210 \\
\hline 2006 & 12 月 3 日 & 6 & 20 & & & \\
\hline 2006 & 12 月4日 & 7 & 60 & & & \\
\hline 2006 & 12月15日 & 18 & & 530 & 300 & 260 \\
\hline 2007 & 1月19日 & 53 & & 580 & 300 & 250 \\
\hline 2007 & 2 月19日 & 84 & & 390 & 270 & 250 \\
\hline 2007 & 2 月27日 & 92 & 30 & 610 & 320 & 270 \\
\hline 2007 & 4月18日 & 142 & & 580 & 300 & 250 \\
\hline 2007 & 5 月21日 & 175 & & 360 & 220 & 200 \\
\hline 2007 & 6月19日 & 204 & & 370 & 220 & 190 \\
\hline 2007 & 7月17日 & 232 & & 370 & 220 & 190 \\
\hline 2007 & 8月7日 & 253 & 30 & 220 & 200 & \\
\hline 2007 & 8月8日 & 254 & 30 & 500 & 270 & \\
\hline 2007 & 8月9日 & 255 & & 630 & 330 & \\
\hline 2007 & 8 月17日 & 263 & & 580 & 320 & 230 \\
\hline 2007 & 9月18日 & 295 & & 580 & 330 & 230 \\
\hline 2007 & 10月26日 & 333 & & 480 & 260 & 210 \\
\hline 2007 & 12月11日 & 379 & & 320 & 310 & 190 \\
\hline 2008 & 2月21日 & 451 & & 440 & 330 & 190 \\
\hline 2008 & 3 月25日 & 483 & 20 & 480 & 390 & 200 \\
\hline 2008 & 5 月8日 & 527 & & 470 & 300 & 180 \\
\hline 2008 & 5 月29日 & 548 & & 460 & 280 & 190 \\
\hline 2008 & 10月8日 & 680 & & 480 & 280 & 190 \\
\hline 2008 & 11月26日 & 729 & & 380 & 230 & 170 \\
\hline 2009 & 1月27日 & 791 & 30 & 520 & 280 & 180 \\
\hline 2009 & 7 月3日 & 949 & & 390 & 230 & 170 \\
\hline 2009 & 8月23日 & 1000 & & & & \\
\hline 2009 & 11月7日 & 1076 & & & & \\
\hline
\end{tabular}

界面活性剂濃度、対イオン剂濃度、 $\mathrm{p} \mathrm{H}$ 、鉄、亜鈆、銅、 亜硝酸イオンは循環水をサンブリングして、定量分析を実施 している。本庁舎では実証実験後も超音波流量計の計測も引 き続き行っており、流量変動がないか、チェックしている。 試験開始から、現在までの濃度測定結果を表 1 に示した。こ の間、年 2 回以上(冷・暖房切り替え)の追加投入も実施して おり、2009年8月に1000日目を過ぎても現在も流量も維持、 濃度も安定していることが確認できる。

\section{4-6 最終評価}

省エネルギーセンターの試算によると、空調設備全体に占 める空調水搬送の割合は $2.6 \%$ であり、表 3 には（独）産総 研調查による札幌市役所本庁舎の各エネルギー項目の定格 容量を示す。この半分以上が削減できた本実証試験の結果は インバクトの高いものである。

表3 札䖧市役所本庁舎の各機器のエネルギ一消費

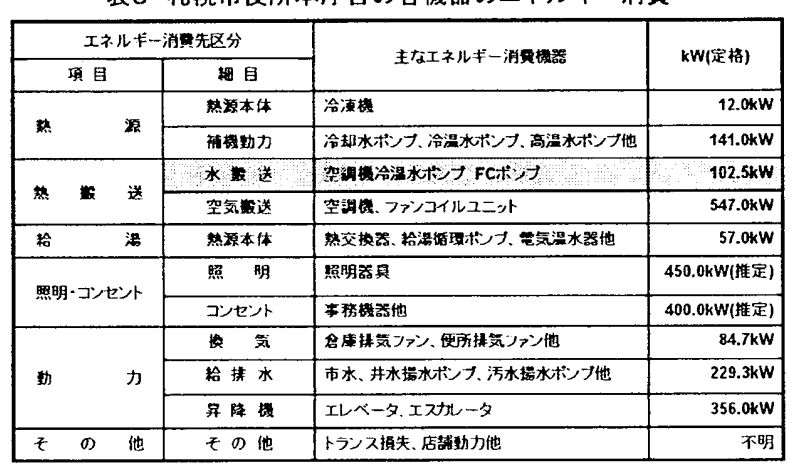

資料提供 (独) 産業技術総合研究所エネルギー技術研究部門

$50 \mathrm{~Hz}$ 運転を $35 \mathrm{~Hz}$ 運転にすると約 $65 \%$ の省エネになる。 $37 \mathrm{kw}$ のポンブ 10 時間/日，240日/年尰転され、電力単価 11 冈 $/ \mathrm{kWh}$ とすると $58,000 \mathrm{kWh}$ の節電、 630,000 節約 32 ton- $\mathrm{CO}_{2}$ 削減となる。

抵抗低減剤を用いた省エネルギー技術の確立、普及に向け て活動をしてきて、今回札幙市役所での実証実験で得られた
経験とデータの蓄積の成果は大きい。初の寒冷地での実績も 得られた。実証試験の場合、施設側の協力関係が重要である。 空調機器への悪影響もなく、省工ネ運転が今も行われている ことは、今後の展開に期待ができる。

\section{LSP-01 の導入実績}

本稿でホしした札幌本打舎の他、我々のグループが LSP-01 を使用して行ってきた省エネルギープロジェクトは、試験導 入を含めて 120 施設での実績がある。詳細なデータのすべて は開示されていないが、近年では、東京都内のオフィスビル、 自動車工場、空港関係、病院、半導体工場に導入をしている。 表 3 に導入実績の概要を示した。

\begin{tabular}{|l|c|}
\multicolumn{2}{|c|}{ 表4 LSP-01 の実績 } \\
\hline 公共施設関係 & 導入数 \\
\hline 病 院 関 係 & 26 \\
\hline ホテル関係 & 7 \\
\hline オフィスビル & 8 \\
\hline エ場 関 係 & 17 \\
\hline 商業施設関係 & 34 \\
\hline 研究機関関係 & 13 \\
\hline
\end{tabular}

\section{6. 最後に}

冒頭に書いたように、(財)地場産業振興センターは 1991 年に産学公から構成する研究会グルーブを発足させた。その 後、周南市の中小企業によってエルエスピー協同組合を設立 し、さらに山口大学との共同研究を継続しながら省エネル ギ一技術の確立と普及を行ってきた。この業績に対し、平成 21 年 3 月にグリーン・サステイナブル ケミストリー (GSC) ネットワークより GSC 賞が贈られ、さらに環境大臣賞を授与 された (任伯准教授 (山口大学)、徳原、松村理事長（エルエ スビー協同組合)。今後ともこの技術の普及を図っていくと ともに、他の省工技術との組み合わせも考えた総合的な省 エネ提案を進めて行きたいと考えている。

引用文献

1）薄井、徳原: “界面活性剂を用いた省エネルギー冷暖房 システムの開発”：化学工学会年会要旨集, L.101, 206(1994) 2）川口、藤原、武内、徳原:”トムズ効果によるビル空調 システムの省エネルギー”，日本機械学会論文集，10 111, 1079 (2008)

3）佐伯、徳原、松村ら:”界面活性剂による抗力減少効果 の空調設備への忘用”：日本機械学会論文集 (B)，68，669, 1482-1488 (2002)

4）徳原、松村、佐伯：“抗力減少剤の空調システムの応 用”，日本機械学会流体部門講演論文集，1007，（2000） 